\title{
Solid Electrolyte Nanometer Switch
}

\author{
Toshitsugu Sakamoto Non-member (NEC, sakamoto@frl.cl.nec.co.jp) \\ Shunichi Kaeriyama Non-member (NEC) \\ Masayuki Mizuno Non-member (NEC) \\ Hisao Kawaura Member (NEC) \\ Tsuyoshi Hasegawa Non-member (NIMS) \\ Kazuya Terabe Non-member (NIMS) \\ Masakazu Aono Non-member (NIMS)
}

Keywords: solid electrolyte, electrochemical reaction, programmable logic

Cell-based integrated circuits (CBICs) are widely used for ASIC platforms because of their high performance and low die-cost. However, non-recurring expense (NRE) is large, and the turnaround time (TAT) is long. With MOSFETs scaling down, NRE has been rising and TAT increasing. Accordingly, field programmable devices such as Field programmable gate array (FPGA) has become attractive increasingly. FPGAs have such advantages as a short TAT and low NRE.

An FPGA is composed of logic cell arrays, interconnections, and switches at each cross-point. The switch consists of an SRAM and a pass transistor and has a size of $120 \mathrm{~F}^{2}$. The switch occupies a large area in the chip. To minimize the number of switches and to maintain the logic cell occupancy, each cell has a coarse granularity $\left(>10^{4} \mathrm{~F}^{2}\right)$ with high functionality. As a result, the FPGA is costly and has poor cell usage efficiency. Moreover, the large ON resistance of the pass transistor causes routing delay in the interconnection.

We have developed a solid electrolyte switch that can achieve FPGA with low die cost and high performance. The novel switch comprises a $\mathrm{Cu}_{2} \mathrm{~S}$ film sandwiched between two metals $(\mathrm{Cu}$ and $\mathrm{Ti}) . \mathrm{Cu}_{2} \mathrm{~S}$ is a $\mathrm{Cu}$-ionic conductor and ptype semiconductor. The switch has two conducting states $(\mathrm{ON} / \mathrm{OFF})$, which are altered by applying a positive or negative voltage to the metal and persist without a power supply. The conductance switching can be explained by creating and annihilating a metallic bridge inside the $\mathrm{Cu}_{2} \mathrm{~S}$ film. The switch has a simple structure of potentially $4 \mathrm{~F}^{2}$ and has low ON resistance $(<100 \Omega)$, which is lower than those of FETs by two orders of magnitude.

When the solid-electrolyte switch is substituted for the SRAM-based switch in the FPGA, the switch size can be reduced to one thirtieth and the ON resistance can be re- duced to one fortieth. This substitution thus provides two distinct advantages. First, the chip size of the novel field programmable device can be reduced. Second, the routing delay falls because the ON resistance of the switch is very low. We estimate the routing delay reduction ratio to be from 20 to $40 \%$ using typical parameters of the interconnections. Consequently, we can reduce the chip size further and also reduce the power consumption.

To demonstrate the potential of our novel switch for programmable CBICs, we fabricated a $4 \times 4$ crossbar switch. The crossbar switch is a fundamental component in field programmable devices. The crossbar switch can be composed of a solid-electrolyte switch only. If the relationship between the program voltage $\left(\mathrm{V}_{\mathrm{PP}}\right)$ and the threshold voltage $\left(\mathrm{V}_{\mathrm{TH}}\right)$ of the switch is given by $\mathrm{V}_{\mathrm{TH}}<\mathrm{V}_{\mathrm{PP}}<2 \mathrm{~V}_{\mathrm{TH}}$, the crossbar switch can be properly programmed. However, because each fabricated switch had a wide $\mathrm{V}_{\mathrm{TH}}$ distribution, programming could not be properly done. Accordingly, we used a pass transistor in the cross-point switch to program each element.

The diagonal elements of the matrix were programmed to $\mathrm{ON}$, and the off-diagonal elements were programmed to OFF. Then, X0 through X3 were successfully transferred to Y0 through Y3. Second, when the crossbar switch was reconfigured, proper output signals were obtained. This reconfiguration was repeatedly made. The operation voltage was $1.8 \mathrm{~V}$, which was larger than the threshold voltage of the switch. The state of the switch therefore changed during normal operation. In the experiment, the normal operation was limited to within $2-8 \mathrm{~ms}$. To achieve stable operation we have to increase the $\mathrm{V}_{\mathrm{TH}}$ of the switch. To program each switch without a pass transistor we should improve the distribution of $\mathrm{V}_{\mathrm{TH}}$. 


\section{固体電解質ナノスイッチ}

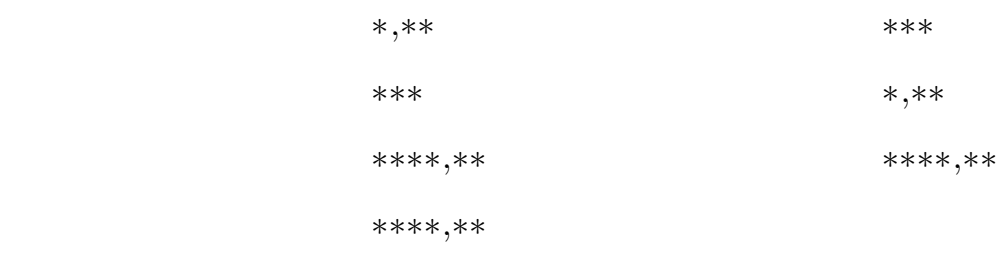

Solid Electrolyte Nanometer Switch

Toshitsugu Sakamoto*,**, Non-member, Shunichi Kaeriyama***, Non-member, Masayuki Mizuno***, Non-member, Hisao Kawaura $^{* * *}$, Member, Tsuyoshi Hasegawa ${ }^{* * * *, * *}$, Non-member, Kazuya Terabe****,**, Non-member, Masakazu Aono****,**, Non-member

We have investigated solid-electrolyte switches that utilize electrochemical reactions (deposition and dissolution) of metallic ions. The switch turns off or on when a metallic bridge electrochemically forms or dissolves in the solid electrolyte. Each state is nonvolatile and the switching is repeatable up to $10^{5}$ cycles. The promising application is a programmable switch in a field programmable logic because of its small size $(<30 \mathrm{~nm})$ and low ON-resistance $(<100 \Omega)$. In this paper, we will discuss the electrical characteristics, operation principle, and applications of the solid electrolyte switch.

キーワード : 固体電解質, 電気化学反応 , プログラマブルロジック

Keywords: solid electrolyte, electrochemical reaction, programmable logic

\section{1. まえがき}

固体電解質は，弚の中を金属イオンが自由に動くことの できる固体材料であり, 電池やセンサ等に広く応用されて いる。固体電解質中のイオン伝導を利用したスイッチング 素子も近年幾つか報告されている(1) (6)。スイッチング動 作は, 電気化学反応によって電極間に金属架橋が生成ある いは消滅することによって実現されている。ここで述べる 硫化銅 $\left(\mathrm{Cu}_{2} \mathrm{~S}\right)$ も固体電解質の一つであり, 銅イオンが電

*日本電気 (株) 基礎 $\cdot$ 環境研究所

厂 305-8501 茨城県つくば市御幸が丘 34

Fundamental \& Enviromental Research Labs., NEC Corp., 34 Miyukigaoka, Tsukuba, Ibaraki 305-8501, Japan

** 科学技術振興機構

干 332-0012 埼玉県川口市本町 4-1-8

Japan Science and Technology Agency,

4-1-8 Honmachi, Kawaguchi, Saitama 332-0012, Japan

*** 日本電気 (株) システムデバイス研究所

干 229-1198 神奈川県相模原市下九沢 1120

System Device Labs., NEC Corp.,

1120 Shimokuzawa, Sagamihara, Kanagawa 229-1198, Japan

*****物質・材料研究機構ナノマテリアル研究所

T 305-0047 茨城県つくば市並木 1-1

Nanomaterial Lab., National Institute for Material Science, 1-1 Namiki, Tsukuba, Ibaraki 305-0044, Japan
界に従って硫化銅中を移動できる。

電極間に生成した金属ブリッジのサイズはナノメーター のオーダーであることから，素子のサイズを微細化するこ とが可能である。さらに，金属の比抵抗は非常に低いこと から, 既存の半導体では達成できない低オン抵抗を実現で きる。従来の半導体スイッチにない小型・低抵抗性を備え るため, ロジック回路の再構成用スイッチとして用いれば， 高性能なプログラマブルロジックか実現できる。

\section{2. 素子構造および電流電圧特性}

図 1 に固体電解質ナノスイッチの構造を示す ${ }^{(3)}{ }^{(4)}$ 。本素 子は 2 端子構造であり，固体電解質の硫化銅 $\left(\mathrm{Cu}_{2} \mathrm{~S}\right)$ が $2 つ$ の金属電極で挟まれた構造を持つ。上部電極は $\mathrm{Au} / \mathrm{Pt} / \mathrm{Ti}$ の積層構造からなる。本素子の接合部は絶縁膜 (ここでは Calixarene)の開口部で規定される。

素子の作製方法について説明する。まず, $\mathrm{SiO}_{2} / \mathrm{Si}$ 基板 上に $\mathrm{Cu}(120 \mathrm{~nm}) / \mathrm{Au}(50 \mathrm{~nm})$ を $\mathrm{E}-\mathrm{Gun}$ 蒸着によって成膜 し，0.025M の硫化ナトリウム溶液中でアノード分極法に より表面を硫化する。このとき，硫化銅表面には凹凸が見 られたが , これは $\mathrm{Cu}_{2} \mathrm{~S}$ のグレイン構造を反映していない。 TEM 観察の結果, 本手法で成長した $\mathrm{Cu}_{2} \mathrm{~S}$ はアモルファス 構造からなることが分かっている。次に, 電子線露光によ りパターニングしたレジストをマスクに，アルゴンイオン 
(a)

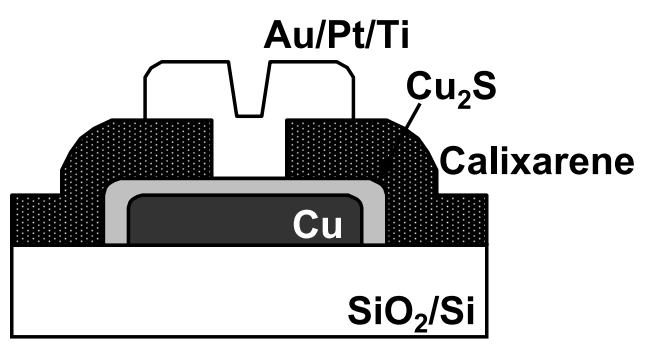

(b)

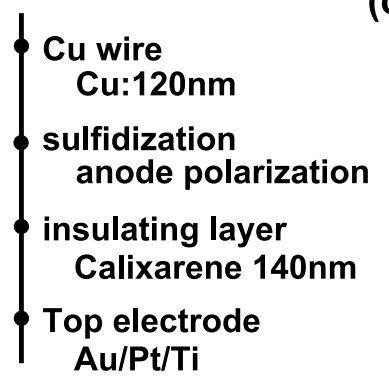

(c)

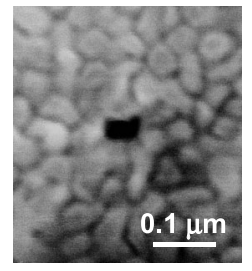

図 1 (a) 固体電解質ナノスイッチの模式図 (固 体電解質である $\mathrm{Cu}_{2} \mathrm{~S}$ が 2 つの金属 $(\mathrm{Cu}$ と $\mathrm{Ti})$ によって挟まれている)，(b) 作製工程，(c) 孔周 辺の電子顕微鏡 $(\mathrm{SEM})$ 写真

ミリングにより $\mathrm{Cu}_{2} \mathrm{~S} / \mathrm{Cu} / \mathrm{Au}$ を加工する。さらに，ネガ 型電子線レジストであるカリックスアレーン (Calixarene, 厚さ $140 \mathrm{~nm})$ を塗布して，電子線露光技術によりコンタ クト孔を形成し絶縁層とする。最後に，ポジ型電子線レジ ストである PMMA を用いて上部電極パターンを形成し， $\mathrm{Au}(120 \mathrm{~nm}) / \mathrm{Pt}(20 \mathrm{~nm}) / \mathrm{Ti}(3 \mathrm{~nm})$ を E-Gun 蒸着により成 膜し , リフトオフにより上部電極とする。今回作製した最 小接合サイズ $(30 \mathrm{~nm})$ の SEM 写真を図 1(c) に示す。接合 サイズは孔径によって規定される。

図 2 に室温における電流電圧特性を示す。横軸の電圧は 銅電極に対する上部電極の電圧を示す。素子作製直後では， 電子伝導度は $7 \mathrm{nS}$ 以下 (測定限界以下) と非常に小さく, $\mathrm{OFF}$ 状態にある。電圧を負側に大きくすると $-0.28 \mathrm{~V}$ 付 近で電子伝導度が急激に増加し $(\sim 50 \Omega)$, ON 状態に遷移 する。印加電圧を $0 \mathrm{~V}$ 方向に戻して行くと，オーム則に従 い直線的に電流の絶対值は減少する。引き続き電圧を正側 に大きくしてゆくと，0.07V 付近で突如 OFF 状態に転じ る。ON 及び OFF 状態は，不揮発的に維持される。

電流スイッチングは $\mathrm{Cu}_{2} \mathrm{~S}$ 中の $\mathrm{Cu}$ イオンが電気化学反 応によって金属 $\mathrm{Cu}$ となって析出することで起こる。図 2 下図にスイッチングの原理図を示す。上部電極 $(\mathrm{Ti})$ に負電 圧を印加すると， $\mathrm{Cu} / \mathrm{Cu}_{2} \mathrm{~S}$ 界面で，

$$
\mathrm{Cu} \rightarrow \mathrm{Cu}^{+}+\mathrm{e}^{-}
$$

なる酸化反応が起こり， $\mathrm{Cu}$ は $\mathrm{Cu}$ イオンとして $\mathrm{Cu}_{2} \mathrm{~S}$ マト

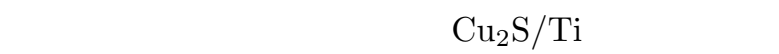

$$
\mathrm{Cu}^{+}+\mathrm{e}^{-} \rightarrow \mathrm{Cu}
$$

なる還元反応が起こり， $\mathrm{Cu}_{2} \mathrm{~S}$ 中の $\mathrm{Cu}$ イオンは金属とな
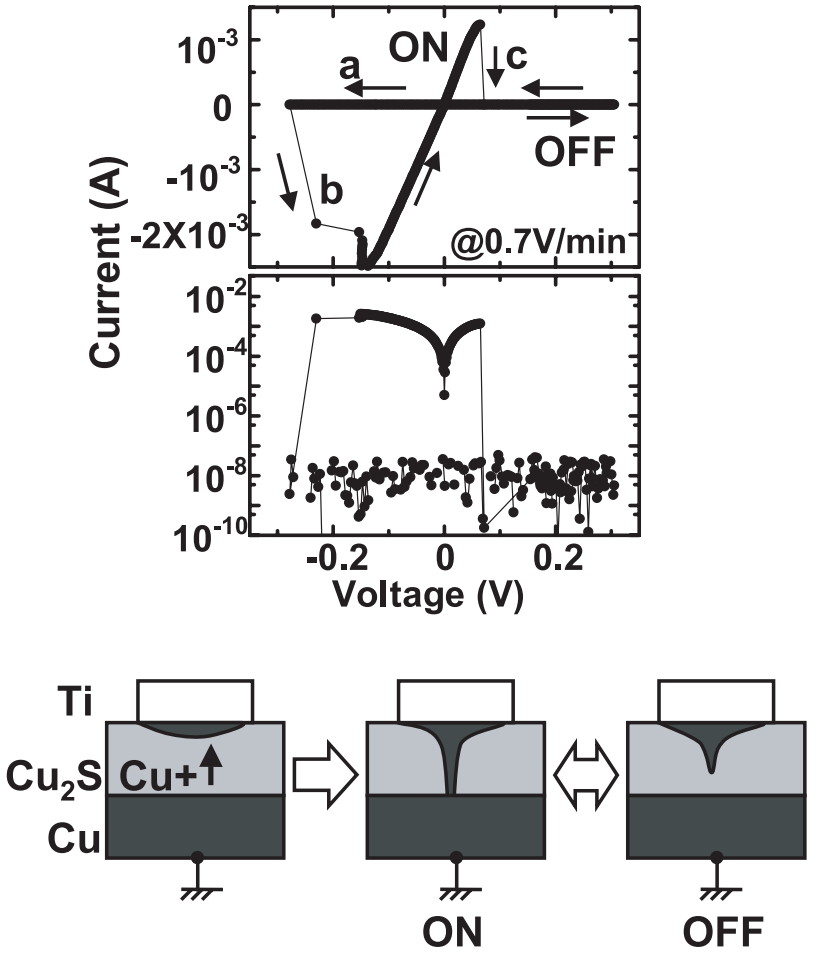

a.

b.

c.

図 2 直径 $30 \mathrm{~nm}$ の接合サイズを備えた固体電解 質ナノスイッチの電流電圧特性 (上部電極に電圧 が印加され， $\mathrm{Cu}$ 電極は電流アンプを介して接地 されている。下の図はスイッチングの原理を示し ている。

り析出する (図 2:a.)。これは電気化学反応の一種であり， 固体電解質である $\mathrm{Cu}_{2} \mathrm{~S}$ を $\mathrm{CuSO}_{4}$ 水溶液等の電解質 (液 体)で置き換えると理解しやすい。上記反応を続けると上 部電極上の $\mathrm{Cu}$ の析出か増え, やがては上部電極と $\mathrm{Cu}$ 電 極との間にブリッジが形成され ON 状態となる (図 2:b.)。 ブリッジは接合全域にわたって形成されるのではなく，以 下の実験事実から，接合の一部に局所的に形成されると考 えられる。

$30 \mathrm{~nm}$ から $0.3 \mu \mathrm{m}$ までの接合サイズ (図 1 (c) の孔径に 相当, $\mathrm{Ti}$ と $\mathrm{Cu}_{2} \mathrm{~S}$ が接する面積) の異なる素子について， $\mathrm{ON}$ 電流と OFF 電流を調べた (図 3:a)。光の結果, OFF 電流は接合サイズに大きく依存するのに対し，ON 電流は 接合サイズにはほとんど依存しなかった。これは, OFF 電 流力接合全域で流れるのに対し，ON 電流は接合中の局所 的な箇所を介して流れることを示している。 $30 \mathrm{~nm}$ の極微 細接合においても動作が可能であることを考えると，形成 されるブリッジの太さは $30 \mathrm{~nm}$ 以下であることも推測され る。また， ON 状態では, ごく少数本のブリッジが形成さ れていると予測される。これは，一旦どこかでブリッジが 形成されると，両電極間が低抵抗ブリッジで結ばれ大きな 電圧印加が困難になり，これ以上ブリッジが成長できなく なるからである。ON 状態では完全なオーミック特性が得 られ，兴の抵抗は数 $10 \Omega$ 程度と低い。これはブリッジが金 
属 $(\mathrm{Cu})$ で形成されるためである。温度依存性も，温度が 低いほど低抵抗を示し, フォノン散乱で電子伝導度が決ま る金属特有の性質を示す (図 3:b)。

次に上部電極を正にバイアスすると，上記電気化学反応 が逆方向に進行するため, ブリッジ中の $\mathrm{Cu}$ がイオン化し て $\mathrm{Cu}_{2} \mathrm{~S}$ マトリックス中に溶け込み, $\mathrm{Cu}_{2} \mathrm{~S}$ 中の $\mathrm{Cu}$ イオ ンは $\mathrm{Cu}$ 電極 - $\mathrm{Cu}_{2} \mathrm{~S}$ 界面で還元され金属として析出する (図 2:c.)。この反応を続けると,やがてはブリッジが切れ $\mathrm{OFF}$ 状態となる。ON 電流が接合サイズにほとんど依存 しないのに対し，OFF 電流は接合サイズに依存するため， $\mathrm{ON} / \mathrm{OFF}$ 電流比は接合サイズが小さいほど大きい。接合 サイズが $0.3 \mu \mathrm{m}$ 及び $30 \mathrm{~nm}$ の場合, $\mathrm{ON} / \mathrm{OFF}$ 電流比は光

(a)

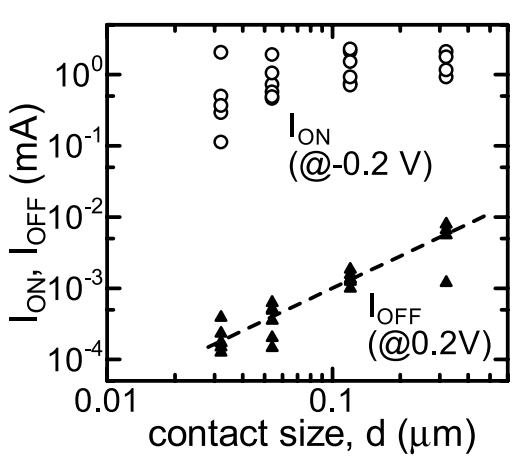

(b)

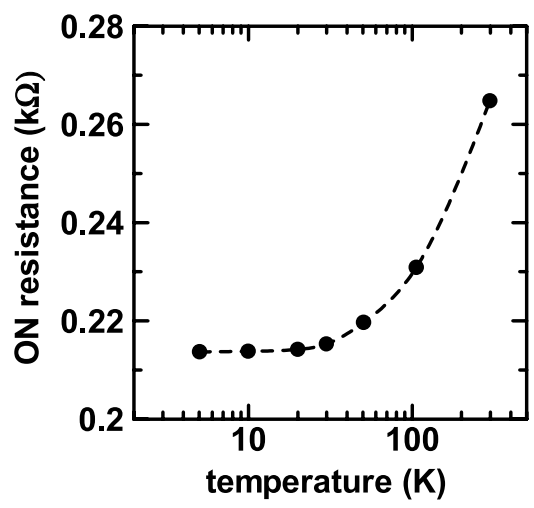

図 3 (a) ON 電流と OFF 電流の接合サイズ依存 性 , (b) ON 抵抗の温度依存性。

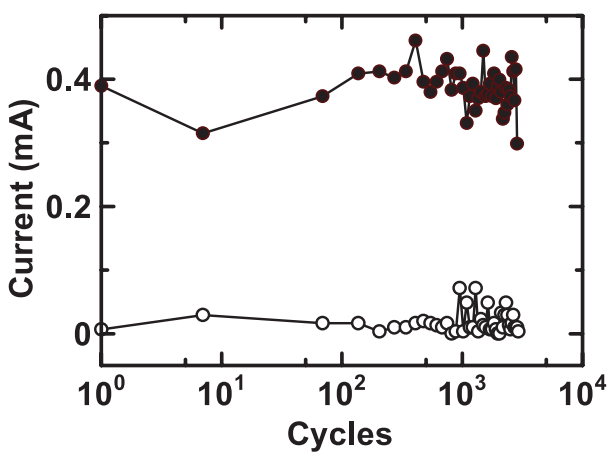

図 4 パルス電圧によってスイッチングした場合 の $\mathrm{ON}$ 電流 (黑丸), $\mathrm{OFF}$ 電流 (白丸) のサイクル 回数依存性（接合サイズ $30 \mathrm{~nm}$ の素子を用いた。）

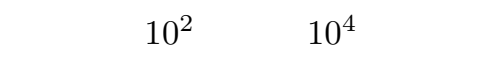

パルス電圧入力によってスイッチングを行い, サイクル 耐性および保持特性を調べた。 $-0.4 \mathrm{~V}$ の負の電圧パルスに より $\mathrm{OFF}$ から $\mathrm{ON}$ 状態へ状態を遷移させ , $+0.4 \mathrm{~V}$ の正 のパルス電圧により ON から OFF 状態へ遷移させ，また， $-0.1 \mathrm{~V}$ の読出しパルス電圧 (各パルス幅 $1 \mathrm{msec}$ ) を加えた 時の電流值の大小により，ON 状態または OFF 状態を読 み取った。ON/OFF 状態間の遷移時間は $100 \mu \mathrm{sec}$ 程度で あり，パルス電圧の増大により遷移時間は短くなる傾向に ある。図 4 に示すように , スイッチングサイクル数は $10^{3}$ サイクル程度であり, 弚の後は ON または OFF 状態のい ずれかの状態に留まる。この状態書換えの破綻は，素子の 破壞によるものではなく，閾值電圧のわずかな変化による ものである。接合径の大きな素子ではより多くの繰り返し が可能で, 接合サイズ $0.3 \mu \mathrm{m}$ の素子において $10^{5}$ サイクル まで動作が確認されている。

以上述べたように，本固体電解質ナノスイッチは数十 $\mathrm{nm}$ までの微細化が可能で, 高い ON/OFF 比, 低 ON 抵抗と いった特徵を備えている。本スイッチをプログラマブルロ ジックにおける配線や機能の切り替えための再構成スイッチ に用いれば, 本スイッチがコンパクトでかつ低抵抗であるこ とから，高性能で汎用性の高いプログラマブルデバイスが 実現できる(7)。また，メモリに用いた場合には，ON/OFF 比が高いことから，読み出しマージンが大きく，高速読み 出しが可能となる。さらに, 素子構造か簡便であるため, ス タック化により低コスト化が可能になる。また，高エネル ギー粒子によるソフトエラーに対する耐性も高い。

3. プログラマブルロジック応用

特定用途向け集積回路 (ASIC) のプラットフォームには， セルベース IC (CBIC) が広く用いられてきた。CBIC はあ らかじめ用意された基本ロジックセルを配置, 結線する方 式の ASIC で, 配置や結線は半導体製造プロセス中で行わ れる。CBIC はチップ単価か安価て性能が高い一方で, 製造

\section{Conventional FPGA}
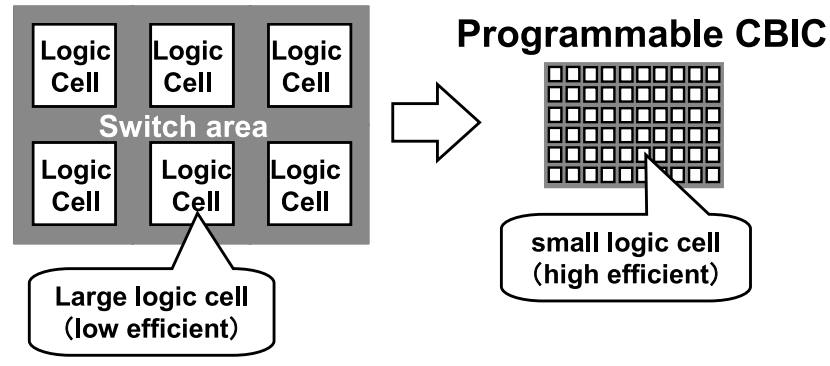

图 5 従来型 FPGA とプログラマブル $\mathrm{CBIC}$ の 模式図 (白色の部分がロジックセル，灰色の部分 がスイッチの領域を表している。本固体電解質ナ ノスイッチを適応することによって , 小さなサイ ズのロジックセルの使用が可能となり，チップサ イズが縮小し性能が向上する。） 
に要するマスク費用や開発費用等の初期コストが高く，ま た開発期間も長くなるという課題がある。光のため, 近年, 機器開発における競争の激化も手伝って, 機器メーカーの 手元で回路組み換えができ, 機器開発期間を大幅に短縮で きるプログラマブルロジックがその市場を大きく伸ばして る。プログラマブルロジックはロジックセル , セル間を接続 する配線，配線を切り替えるスイッチから構成されている。

代表的なプログラマブルロジックである FPGA におい て，配線間を接続するスイッチは SRAM とパストランジ スタで構成されている。この SRAM スイッチは, 面積が 大きく $\left(120 \mathrm{~F}^{2}, \mathrm{~F}\right.$ は LSI の最小加工寸法), ON 時の抵抗 が高い(数 $\mathrm{k} \Omega)$ 。午のため, 接続スイッチの使用数を減ら すことを目的に，CBICよりも約 100 倍トランジスタ数の 多いロジックセル (セル面積 $\left.>10^{4} \mathrm{~F}^{2}\right)$ が用いられている (図 5)。炎の結果 , チップサイズが大きくチップ単価が高く なるという課題や，回路の使用効率悪化に伴うロジックセ ル組み合わせ自由度や並列演算処理性能の低下により，プ ログラマブルロジックの回路応用範囲が CBIC に比べ限ら れるという課題がある。

前節で述べたように，固体電解質スイッチは，低抵抗で 超小型という 2 つの特徵を持つ。スイッチの構造が簡単で あるために $4 \mathrm{~F}^{2}$ のサイズが可能である。さらに，ON 抵抗 は $100 \Omega$ 以下であり, 半導体トランジスタに比べると数桁 小さい。本固体電解質スイッチを用いると，CBIC 並みに 応用範囲の広いプログラマブルロジック (プログラマブル CBIC) が実現できる。

固体電解質スイッチを FPGA における SRAM スイッチ と比較すると, スイッチの面積が 30 分の 1 , ON 抵抗が 40 分の 1 程度である。FPGA の配線切り替えスイッチに

(a)

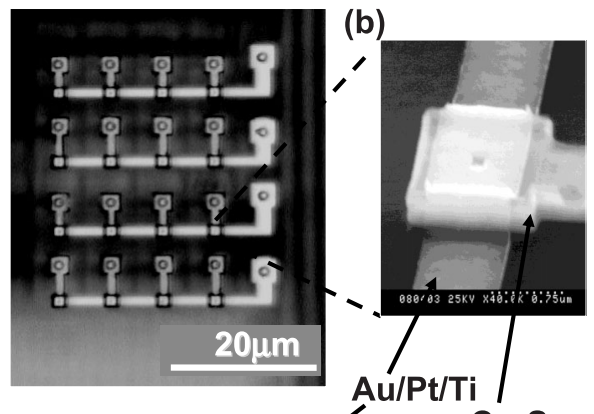

(c)

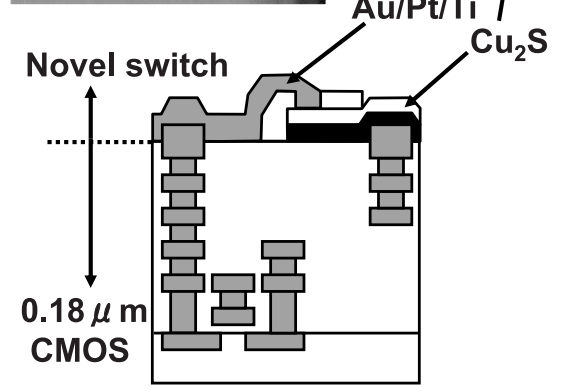

図 $64 \times 4$ クロスバースイッチ ( (a) 平面顕微鏡 写真，(b) 固体電解質スイッチ部分の拡大，

(c) 断面模式図)
固体電解質スイッチを用いた場合, スイッチの面積は無視 でき, チップ面積は半分程度となる。さらに, 少数のトラ ンジスタで構成された小さなロジックセルを用いることに より，面積あたりのセルの使用効率が向上し，チップ面積 は 10 分の 1 程度になると見積もられる (図 5)。炎の結果, チップ単価を大幅に下げることができる。また，ON 抵抗 が低いことから配線遅延は小さくなる。ON 抵抗が 30 分 の 1 の場合には, 配線遅延が $20 \sim 40 \%$ 程度改善されると の計算結果を得ている。チップ面積の縮小と ON 抵抗の低 抵抗化によって，消費電力も大幅に低減できる。

以上のことから，固体電解質スイッチを用いたプログラ

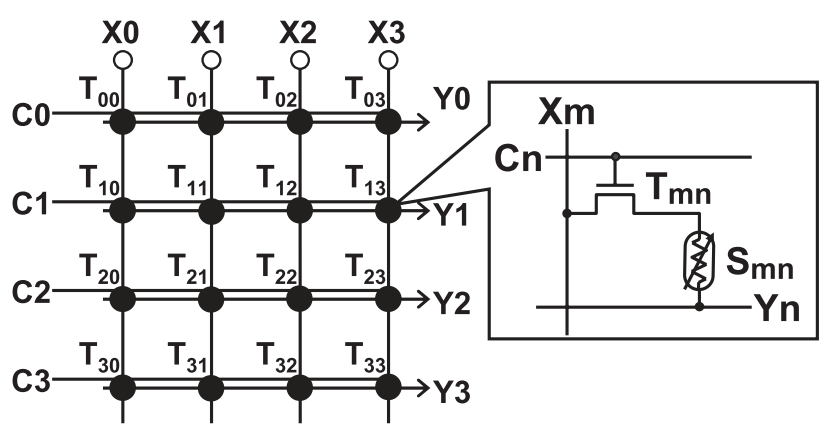

図 $74 \times 4$ クロスバースイッチの回路模式図 (各要素は固体電解質スイッチ $\left(\mathrm{S}_{\mathrm{mn}}\right)$ と選択卜ラ ンジスタ $\left(\mathrm{T}_{\mathrm{mn}}\right)$ から構成され，光れ炎れ，制御線 $\left(\mathrm{C}_{\mathrm{n}}\right)$, 入力 $\left(\mathrm{X}_{\mathrm{m}}\right)$, さらに出力 $\left(\mathrm{Y}_{\mathrm{n}}\right)$ に接続され ている。)

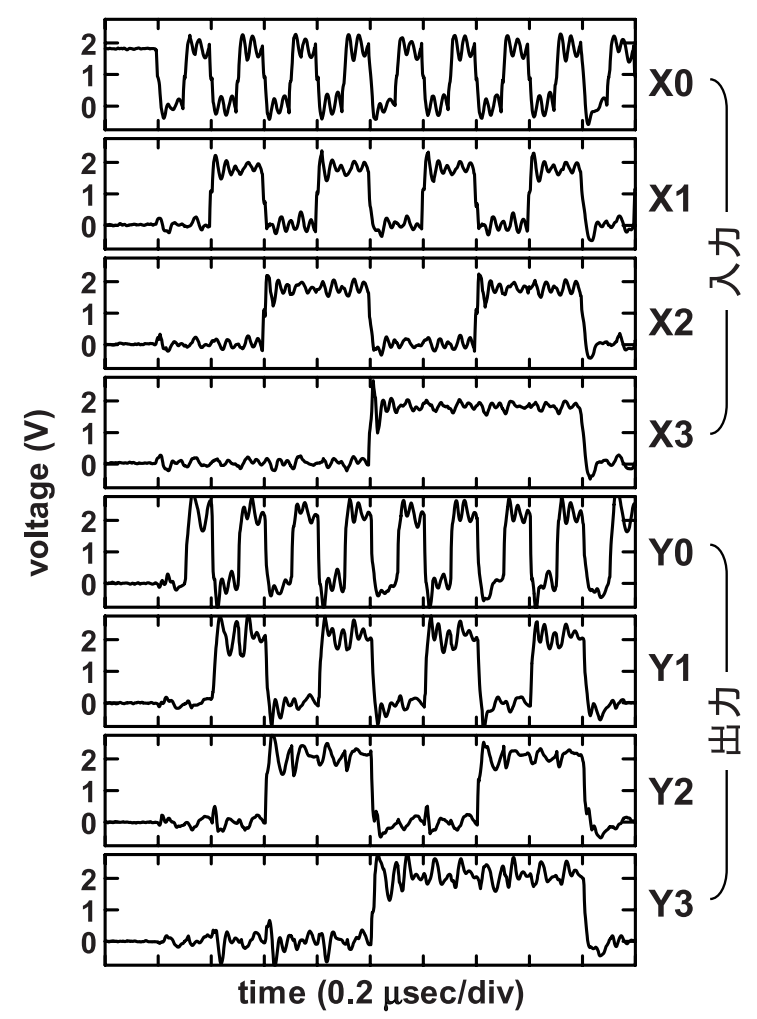

図 8 クロスバースイッチの入力 $(\mathrm{X} 0-\mathrm{X} 3)$ と出 力波形 $(\mathrm{Y} 0-\mathrm{Y} 3)$ 
マブル CBIC は, 低コストで, 高性能 (高動作速度 , 低消 費電力) な新しい ASIC プラットフォームを提供できる。

固体電解質スイッチを用いたプログラマブル CBIC の可 能性を実証するために，4×4 クロスバースイッチを試作 した (図 6)。クロスバースイッチはプログラマブルデバイ スの基本回路要素である。クロスバースイッチは，原理的 に固体電解質スイッチのみから構成することが可能である。 プログラム電圧 $\left(\mathrm{V}_{\mathrm{PP}}\right)$ と固体電解質スイッチ のスイッチ ング電圧 $\left(\mathrm{V}_{\mathrm{TH}}\right)$ が, $\mathrm{V}_{\mathrm{TH}}<\mathrm{V}_{\mathrm{PP}}<2 \mathrm{~V}_{\mathrm{TH}}$ の関係を満た していれば，クロスバースイッチをプログラムできる。し かし, 試作した固体電解質スイッチのスイッチング電圧が ばらついており，一部のスイッチが上記の関係を満たして いなかったため，適切にプログラムすることができなかっ た。乥のため, 今回は各クロスポイントにパストランジス ターを導入することにより, 各スイッチのプログラミング を行った(図 7)。

$0.18 \mu \mathrm{m}$ CMOS 技術を用いてパストランジスタ，制御回 路および入出力バッファーを形成した。固体電解質スイッ チは配線層の最上層に形成した。固体電解質スイッチの作 製時には高温となる工程等を含まないために，本作製工程 によって下層の配線層やトランジスターには影響はない。

図 7 において, スイッチ $\mathrm{S}_{\mathrm{mn}}$ の内 , 対角成分 $(m=n)$ を ON とし, 非対角成分 $(m \neq n)$ を OFF にプログラムし た。図 8 に入出力信号の実験結果を示す。X 0 から X3 は， Y0 から Y 3 人伝達されていることがわかる。一方， ON と OFF 状態のスイッチが上記の転置の位置になるようにプ ログラムすると，X0 から X3 は，Y 3 から Y 0 へ伝達され た。さらにこれらの再構成を交互に行うことができた。固 体電解質スイッチを用いて回路の再構成ができることが示 せた。

ところが, 固体電解質スイッチのスイッチング電圧が動 作電圧 $(1.8 \mathrm{~V})$ よりも小さいために , 信号を伝達している 際に, スイッチの状態か変化してしまう。光のため, 通常 動作は $2 \sim 8 \mathrm{msec}$ 程度に限定される。安定した動作を得 るためには, 固体電解質スイッチのスイッチング電圧を高 める必要がある。また , スイッチング電圧をばらつきを低 減してパストランジスタを取り除く必要がある。

\section{4. まとめ}

固体電解質 $\left(\mathrm{Cu}_{2} \mathrm{~S}\right)$ を用いて $\mathrm{Ti} / \mathrm{Cu}_{2} \mathrm{~S} / \mathrm{Cu}$ 微細積層構造 を作製しスイッチング特性を評価した。接合を $30 \mathrm{~nm}$ まで 微細化しても良好なスイッチング特性が得られた。また，保 持時間は 1 ケ月程度，スイッチング速度は $100 \mu \mathrm{sec}$ (スイッ チング電圧 $0.4 \mathrm{~V}$ の場合) , サイクル数は $10^{3} \sim 10^{5}$ 回で あった。

再構成可能ロジックであるプログラマブル CBIC を提案 した。さらに，固体電解質スイッチを用いた $4 \times 4$ クロス バースイッチの実証を行った。プログラマブル CBIC は， 従来の FPGA に比べて, 安価で高性能な再構成ロジック
が実現でき，応用範囲を拡げることができる。

(平成 17 年 9 月 28 日受付, 平成 18 年 1 月 31 日再受付)

文献

(1) K. Terabe, et al.: "Quantized conductance atomic switch", Nature, Vol.433, pp.47-49 (2005-1)

( 2 ) M.N. Kozicki, et al.: "Can Solid State Electrochemistry Eliminate the Memory Scaling Quandary?", Tech. Dig. of Si Nanoelectronics Workshop, pp.51-53 (2002-6)

(3) T. Sakamoto, et al.: "Reproducible Current Switching in Copper Sulfide Film", Ext. Abst. of the Int. Conf. on Solid State Devices and Materials, pp.264-265 (2002-9)

(4) T. Sakamoto, et al.: "Nanometer-scale Switch Using Copper Sulfide", Appl. Phys. Lett., Vol.82, pp.3032-3034 (2003-5)

(5) R. Symanczyk1, et al.: "Electrical Characterization of Solid State Ionic Memory Elements", Proc. of Non-Volatile Memory Technology Symposium (2004-11)

(6) T. Hasegawa, et al.: "Quantum point contact switch using solid electrochemical reaction", Ext. Abst. of the Int. Conf. on Solid State Devices and Materials, pp.564-565 (2001-9)

( 7 ) T. Sakamoto, et al.: "A Nonvolatile Programmable Solid Electrolyte Nanometer Switch", ISSCC Dig. Tech. Papers, pp.290-291 (2004-2)

阪 本 利 司 (非会員) 1991 年 3 月大阪大学大学院基礎工学

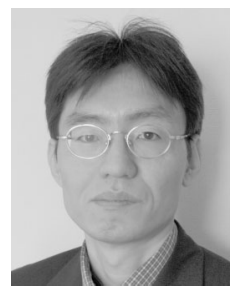
研究科博士前期課程修了。工学博士。同年日本電 気 (株) 入社。1999〜2000 年カリフォルニア工科 大学客員研究員。主としてホットエレクトロンデ バイス, 単一電子デバイス, イオン伝導体デバイ ス等の極微デバイスの研究開発に従事。現在, 日 本電気 (株) 基礎・環境研究所主任研究員。

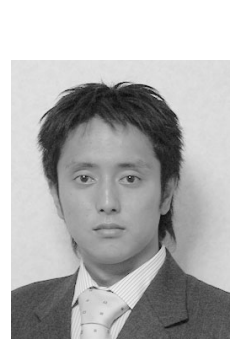

(非会員) 2001 年 3 月東北大学大学院情報科学 研究科博士前期課程修了。同年日本電気 (株) 入 社。高速シリアル伝送回路の研究開発に従事。現 在 , 同システムデバイス研究所勤務。

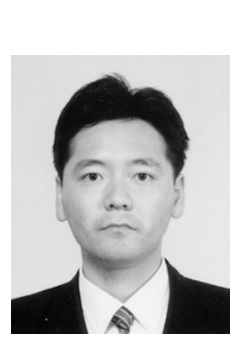

(非会員) 1993 年 3 月大阪大学大学院工学研究科 博士前期課程修了。工学博士。同年日本電気 (株) 入社。1999〜2000 年スタンフォード大学客員研 究員。おもに低電力 MPEG 2 ビデオエンコーダ LSI, 低電力 PLL, 高速クロック分配ネットワー クの研究開発に従事。現在, 日本電気 (株) シス テムデバイス研究所主任研究員。 
川浦久雄 (正員) 1987 年 3 月京都大学大学院理学研究科 博士前期課程修了。工学博士。同年日本電気 (株) 入社。おもにカスタム LSI , 微細 MOSFET 中の 量子効果 , ナノバイオチップ, イオン伝導体デバ イスの研究に従事。現在, 同基礎・環境研究所主 任研究員。

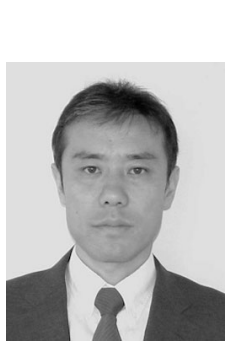

剛 (非会員) 1987 年 3 月東京工業大学大学院総合 理工学研究科博士前期課程修了。同年日立 (株) 入 社。工学博士。1999 年より理化学研究所, 2002 年より物質・材料研究機構勤務。おもにナノプロー ブ, 原子挙動に基づくナノデバイスの研究開発に 従事。現在, 現在, 物質・材料研究機構ナノマテ リアル研究所アソシェートディレクター。
寺 部 - 弥 (非会員) 1992 年 3 月名古屋工業大学工学研究科 物質工学専攻博士課程修了。工学博士。同年名古 屋大学助手, 1996 年理化学研究所を経て, 2001 年物質・材料研究機構入所。おもに走査型電子顕 微鏡を用いた固体電気化学に基づく, 硫化銀を材 料とした原子スイッチなどのナノイオニクスデバ イスの研究開発に従事。現在, 物質・材料研究機 構ナノマテリアル研究所主幹研究員。

青 野 正 和 (非会員) 1967 年 3 月早稲田大学理工学部卒業。

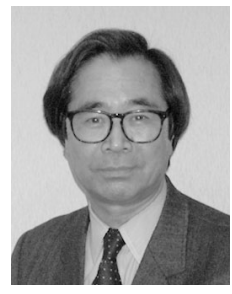
1972 年東京大学工学系研究科博士課程修了。工 学博士。同年無機材質研究所入所。光の後, 理化 学研究所主任研究員 (1986 年 2002 年), 大阪 大学教授 (1996 年〜2005 年) 等を経て, 2002 年 より物質・材料研究機構勤務。この間, JST 創造 科学推進事業「青野原子制御表面プロジェクト」 統括責任者 (1989 年〜1994 年)，同戦略的基礎 研究推進事業「人工ナノ構造の機能探索プロジェクト」研究代表者 (1996 年〜2000 年), 同基礎的研究発展推進事業「新しい量子効果ス イッチの機能素子化」研究代表者 (2001 年〜2004 年), 同国際共同 研究「ナノ量子導体アレープロジェクト」研究代表者 (2003 年〜) を 兼務。現在, 物質・材料研究機構ナノマテリアル研究所所長。 